\title{
Computerized Working Memory Battery (BIMeT-V): Studying the Relation between Working Memory, Verbal Reasoning and Reading Comprehension
}

\author{
Juan Pablo Barreyro*, 1, 2 \\ Orcid.org/0000-0002-1606-1049 \\ Irene Injoque-Ricle ${ }^{1,2}$ \\ Orcid.org/0000-0002-7043-677X \\ Jesica Formoso ${ }^{3}$ \\ Orcid.org/0000-0003-3062-4036 \\ Debora Inés Burin ${ }^{4}$ \\ Orcid.org/0000-0002-2515-719X
}

${ }^{1}$ Instituto de Investigaciones, Facultad de Psicología, Universidad de Buenos Aires,

Buenos Aires, Argentina

${ }^{2}$ CONICET - Consejo Nacional de Investigaciones Cientificas y Técnica,

Buenos Aires, Argentina

${ }^{3}$ Departamento de Investigación en Procesos Básicos, Facultad de Psicología,

Universidad de Buenos Aires, Buenos Aires, Argentina

${ }^{4}$ Facultad de Psicología, Universidad de Buenos Aires, Buenos Aires, Argentina

\begin{abstract}
Working memory refers to all the systems and processes linked to the maintenance and active retention of information relevant to the performance and execution of complex cognitive tasks. Individual differences in working memory have been shown to explain differences in other cognitive abilities, such as comprehension and reasoning. The purpose of the present work was to study the relationship between verbal working memory, verbal reasoning and text comprehension, for which a verbal working memory battery was designed and validated: The verbal Computerized Working Memory Battery (Batería Informatizada de Memoria de Trabajo Verbal [BIMeT-V]). Results showed that the tests administered presented a very good reliability due to internal consistency and, in terms of validity, two latent factors saturated the tests: one of storage and one of storage and concurrent processing of verbal information. Likewise, verbal reasoning skills and the ability to comprehend expository texts are supported by working memory's concurrent storage and processing of verbal information, and to a lesser extent, or with a lesser role, the verbal information storage component.
\end{abstract}

Keywords: Working Memory, comprehension, verbal reasoning.

* Mailing address: Universidad de Buenos Aires, Instituto de Investigaciones, Facultad de Psicología, Av. Independencia 3056, $3^{\circ}$ piso (C1425AAM), Ciudad Autónoma de Buenos Aires, Argentina. Phone: +54-114957-5886. E-mail: jpbarreyro@gmail.com, irene.injoque.ricle@gmail.com and jesica.formoso@gmail.com Support: Instituto de Investigaciones, Facultad de Psicología, Universidad de Buenos Aires - Consejo Nacional de Investigaciones Científicas y Técnica (CONICET). 


\title{
Bateria Computadorizada de Memória de Trabalho (BIMeT-V): Estudo da Relação entre a Memória de Trabalho, o Raciocínio Verbal e a Compreensão de Leitura
}

\begin{abstract}
Resumo
A memória de trabalho refere-se a todos os sistemas e processos ligados à manutenção ativa e à retenção de informações relevantes para a execução de tarefas cognitivas complexas. As diferenças individuais na memória de trabalho mostraram estar ligadas com as diferenças nas habilidades, como a compreensão e raciocínio. O objetivo deste trabalho foi estudar a relação entre a memória de trabalho verbal, o raciocínio verbal e a compreensão, para o qual foi projetada e validada uma bateria de memória de trabalho verbal (Bateria de memória de trabalho verbalizada computadorizada, BIMeT-V). Os resultados mostraram que os testes administrados mostraram uma boa confiabilidade em relação a consistência interna, quanto à validade, dois fatores latentes saturavam os testes: um fator de armazenamento e outro de armazenamento e processamento simultâneo. Da mesma forma, as habilidades de raciocínio verbal e de compreensão são tarefas que são suportadas pela capacidade verbal de armazenamento e processamento simultâneo da memória de trabalho e, em menor grau, ou com um papel menos relevante, com o componente do armazenamento de informações verbais.
\end{abstract}

Palavras-chave: Memória de Trabalho, comprehension, raciocínio verbal.

\section{Batería Computarizada de Memoria de Trabajo (BIMeT-V): Estudio de la relación entre la Memoria de Trabajo, el Razonamiento Verbal y la Comprensión Lectora}

\section{Resumen}

La memoria de trabajo se refiere a todos aquellos sistemas y procesos vinculados con el mantenimiento activo y la retención de información relevante para la ejecución de tareas cognitivas complejas. Diferencias individuales en memoria de memoria han mostrado explicar diferencias en habilidades, tales como la comprensión y el razonamiento. El propósito del presente trabajo consistió en estudiar la relación entre la memoria de trabajo verbal, el razonamiento verbal y la comprensión, para ello se diseño y validó una batería de memoria de trabajo verbal (Batería Informatizada de Memoria de Trabajo Verbal; BIMeT-V). Los resultados mostraron que las pruebas administradas mostraron una muy buena confiabilidad por consistencia interna, y en relación a la validez, dos factores latentes saturaron las pruebas: un factor del almacenamiento y otro de almacenamiento y procesamiento concurrente. Asimismo, las habilidades de razonamiento verbal y de comprensión son tareas que son soportadas por la capacidad verbal de almacenamiento y procesamiento concurrente de la memoria de trabajo, y en menor medida, o con un rol menos relevante el componente de almacenamiento de información verbal.

Palabras clave: Memoria de Trabajo, comprensión, razonamiento verbal.

Working memory refers to all the processes and systems that are linked to the storage and active retention of information, which is relevant for the performance and execution of complex cognitive tasks (Baddeley, 2010, 2012; Cowan, 2012). Although the term, working memory evolved from the concept of short-term memory, they are employed interchangeably (Baddeley, 2012). The multi-componential model proposed by Baddeley $(1986,2007,2010)$ is regarded as one of the most influential models of working memory. The model comprises four different subsystems: the central executive, the visuospatial sketchpad, the phonological loop, 
and the episodic buffer. The central executive may be defined as an active and flexible system that is in charge of the regulation and control of different cognitive processes. It is a multitask coordination system that updates and assigns alternately limited cognitive resources. The visuospatial sketchpad is a subsystem that specializes in the active processing and maintenance of visual and/or spatial representations. The phonological loop may be explained as a verbal information storage system that includes a short-term phonological storage and a sub-vocal rehearsal process; it is used to ensure verbal representations remain active and are prevented from decaying. The episodic buffer (Baddeley, 2010), the last proposed subsystem, is considered to be a temporary storage of information that employs multidimensional codes to integrate representations from the phonological loop, the visuospatial sketchpad, and the long-term memory so as to transform them into a unitary episodic representation.

Since the 1990s and more intensely since 2000, a plethora of studies have shown that working memory plays a crucial role in explaining individual differences in high-level cognitive processes such as reasoning (Colom, Abad, Quiroga, Shih, \& Flores-Mendoza, 2008; Colom, Escorial, Shih, \& Privado 2007; Oberauer, Süb, Wilhelm, \& Wittmann, 2008; Stevenson, Heiser, \& Resing, 2013; Süb, Oberauer, Wittmann, Wilhelm, \& Schulze, 2002) and text comprehension (Cain \& Oakhill, 2014; Calvo, 2004; Just \& Carpenter, 1992; Kendeou, van den Broek, Helder, \& Karlsson, 2014). When individuals construct a mental model of a situation that is described in a reasoning problem or a text, they use the space available in their working memory, principally their verbal working memory, to do so.

Verbal reasoning refers to the ability to abstract, generalize, and establish relationships between concepts or ideas that are present in words, sentences or problems (Bennett, Seashore, \& Wesman, 1992; Bilker, Wierzbicki, Brensinger, Gur, \& Gur, 2014). Different researches show that working memory and verbal reasoning capacity are associated with each other
(Daneman \& Tardif, 1987; Kane et al., 2004; Shah \& Miyake, 1996). Daneman and Tardif (1987) reported that memory span tasks that have verbal and numerical materials show significant correlations with verbal reasoning skills $(r=.61$ y .51, respectively). Shah and Miyake (1996), on the other hand, using the reading amplitude test, found significant correlations of medium intensity with verbal aptitude tests $(r=.45$; SAT). Furthermore, Kane et al. (2004) using the structural equations modeling and confirmatory factor analysis revealed that the storage capacity of working memory and concurrent processing capacity in general are important predictors of verbal reasoning skills; the latter were assessed by analogies, inferences, reading comprehension, verbal associations and syllogisms $(\mathrm{b}=.40 \mathrm{y} \mathrm{b}=$ .29 respectively).

Text comprehension is one of the most complex human cognitive activities (Gernsbacher \& Kaschak, 2013). The activity implies the construction of a coherent representation of discourse in episodic memory (Cornoldi \& Oakhill, 2013; Kendeou et al., 2014; Kintsch, 1998). Furthermore, working memory plays a critical role in text comprehension (Bohn-Gettler \& Kendeou, 2014; Prat, Seo, \& Yamasaki, 2016) because its processing necessitates that the products of previous operations are temporarily stored while the reader integrates the successive information of the text. A meta-analysis performed by Daneman and Merikle (1996) concluded that individual differences in working memory are significantly, but moderately correlated with reading comprehension ability $(r=.30-.52)$. Research has also revealed that short-term storage capacity, assessed by means of simple information storage tasks, is not related to a reader's performance in a comprehension task (Carretti, Borella, Cornoldi, \& De Beni, 2009; Engle, Tuholski, Laughlin, \& Conway, 1999). Daneman et al. (Daneman \& Carpenter, 1980; Daneman \& Merikle, 1996; Hannon \& Daneman, 2001) suggested that readers with low working memory capacity, unlike high capacity readers, have a poorer ability to integrate text information with previous knowledge in order to construct a mental model in working 
memory. In a meta-analysis, Daneman and Merikle (1996) endeavored to understand to what degree working memory affects the more specific aspects of integration processes such as the resolution of lexical ambiguity (Mason \& Just, 2007; Waters \& Caplan, 2004), generation of inferences (Barreyro, Cevasco, Burin, \& Molinari, 2012; Cain \& Oakhill, 2014; Currie \& Cain, 2015) and omission of irrelevant textual details (Sanchez \& Wiley, 2006).

The purpose of the present study was to examine the relationship between verbal working memory, verbal reasoning, and text comprehension (Study 2) by means of a new working memory battery, namely, The Verbal Computerized Working Memory Battery (Batería informatizada de Memoria de Trabajo verbal [BIMeT-V]), which was designed and validated in Study 1 . The construction of a new working memory battery was viewed as being of the utmost importance because in Argentina there were no available instruments to assess this memory system other than those found in intelligence scales (Kaufman \& Kaufman, 1983; Wechsler, 1998, 2003, 2012), which are not specific for this purpose. Because working memory capacity is crucial for cognitive processes such as reading comprehension and reasoning, it was imperative to ascertain whether the measurements obtained from the designed battery related to these cognitive processes. Consequently, the objectives of the project were two-fold. Firstly, a verbal working memory battery (BIMeT-V) was constructed so as to allow the researchers to assess the components responsible for the temporary retention of information as well as the storage and concurrent processing of information. Secondly, the relationship between the verbal components of working memory, verbal reasoning, and text comprehension were examined.

\section{Study 1}

The aim of this study was to construct a battery of verbal working memory in order to assess both the temporal retention of information and the capacity of storage and concurrent process- ing. Four tasks were designed, specifically, two simple and two complex, which are based on the tradition of the evaluation of working memory.

\section{Method}

Participants. The sample consisted of 190 university students, of whom 142 were women $(75 \%)$, between the ages of 18 and 31 years $(M=21.22, S D=2.50)$. Their participation was voluntary and furthermore, their anonymity was respected.

\section{Instruments}

Digit Span. The aim of Digit span is to assess the capacity of storage of verbal information in working memory or short-term memory. Numbers from 1 to 9 are displayed on a computer screen. Each number is displayed by itself for $2000 \mathrm{~ms}$; the interval between each number is $1000 \mathrm{~ms}$. The task, itself, comprises two training trials, namely, one two-digit series, and one three-digit series as well as 24 test trials that are divided into three trials per level. The levels range from two to nine digits that have to be remembered per trial. The participant is expected to retain those numbers and when the word, recall is displayed, he or she is asked to indicate on a digital keyboard which numbers were presented, in the exact order in which they appeared. The task is interrupted when the participant fails to recall two trials on the same level. The participant is awarded a point for each trial he or she recalls correctly.

Letter Span. The purpose of Letter span is the same as Digit span, that is, to assess the capacity of the storage of verbal information in working memory. Furthermore, the same procedure as Digit span is followed; however, letters instead of numbers are employed.

Running Span. The purpose of Running span is to measure the storage capacity and concurrent processing of verbal information in working memory. The participants are told that a series of letters will be presented, but are not informed of how many or that they will be expected to remember the last " $x$ " letters of the series. For levels 2, 3, 4, 5, and 6, they 
are expected to remember the last two, three, four, five and six letters, respectively. The total number of letters that are presented varies per level: three to five letters on level 2; four to six on level 3; five to seven on level 4; six to eight on level 5; and seven to nine on level 6. Each letter appears in the center of the screen for $1000 \mathrm{~ms}$. Furthermore, the time interval between stimuli is $500 \mathrm{~ms}$. When the word, recall is displayed, the participant, by means of a digital keyboard, is required to indicate which were the last " $\mathrm{x}$ " letters presented in the exact order in which they appeared; as noted previously, the quantity the participants are expected to remember is dependent on the level. The test comprises two training trials, namely, one two-letter series and another three-letter series as well as 18 test trials, which are divided into three trials per level. Depending on the level, participants are expected to remember between two and seven letters per trial. As is the case with Digit span and Letter span, the task is discontinued when the participant fails to recall two trials on the same level. Furthermore, one point is awarded for each correct trial.

Letter-Digit Span. The purpose of LetterDigit span is the same as that of Running span, namely, to assess the storage capacity and concurrent processing of verbal information in working memory. For this task, numbers and letters are displayed on the computer screen. However, the participants are informed of how many items will be presented. When the word, recall is presented, the participant is required to indicate by means of a digital keyboard all the numbers and letters that were previously presented; first, the letters in alphabetical order and subsequently, the numbers in ascending order. Each stimulus is presented for $2000 \mathrm{~ms}$; the interval between each stimulus is $1000 \mathrm{~ms}$. The task comprises two training trials, namely, one two-letter/digit series and one three-letter/ digit series as well as 18 test trials, which are divided into three trials per level. Depending on the level, the participants are required to rearrange two to seven stimuli in each trial. The task is discontinued when the participant fails to recall or reorder two trials within the same level correctly. The participants are awarded one point for each correct trial. This is in accordance with the other tasks.

Procedure. The participants were tested in a single session, the duration of which was approximately 30 minutes. They first performed a simple task, namely, verbal working memory storage and subsequently, a complex task, namely, concurrent processing and storage. Thereafter, they performed the other simple task and subsequently, the last complex one. The order of the simple and complex tasks was counterbalanced.

Data Analysis. Firstly, the distributions of the scores were examined and the internal consistency of each score was analyzed by employing Cronbach's alpha. Secondly, in order to determine construct validity, correlations between the tasks were performed in conjunction with exploratory and confirmatory factor analyzes (American Educational Research Association [AERA], American Psychological Association [APA], \& National Council on Measurement in Education [NCME], 2000).

Table 1

Descriptive Statistics, Fit Statistics to a Normal Distribution and Alpha Values

\begin{tabular}{lcccccccc}
\hline & $M$ & $S D$ & Min. & Max. & Skewness & Kurtosis & KS & Alpha \\
\hline Digit span & 15.57 & 3.13 & 9 & 23 & 0.06 & -0.41 & $0.11^{* *}$ & .81 \\
Letter span & 10.45 & 3.30 & 3 & 18 & 0.17 & -0.61 & $0.13^{* *}$ & .83 \\
Letter-Digit span & 14.24 & 2.91 & 6 & 23 & -0.12 & -0.08 & $0.08^{* *}$ & .84 \\
Running span & 5.49 & 2.02 & 1 & 11 & 0.42 & 0.47 & $0.13^{* *}$ & .78 \\
\hline
\end{tabular}

$* * p<.01$. 


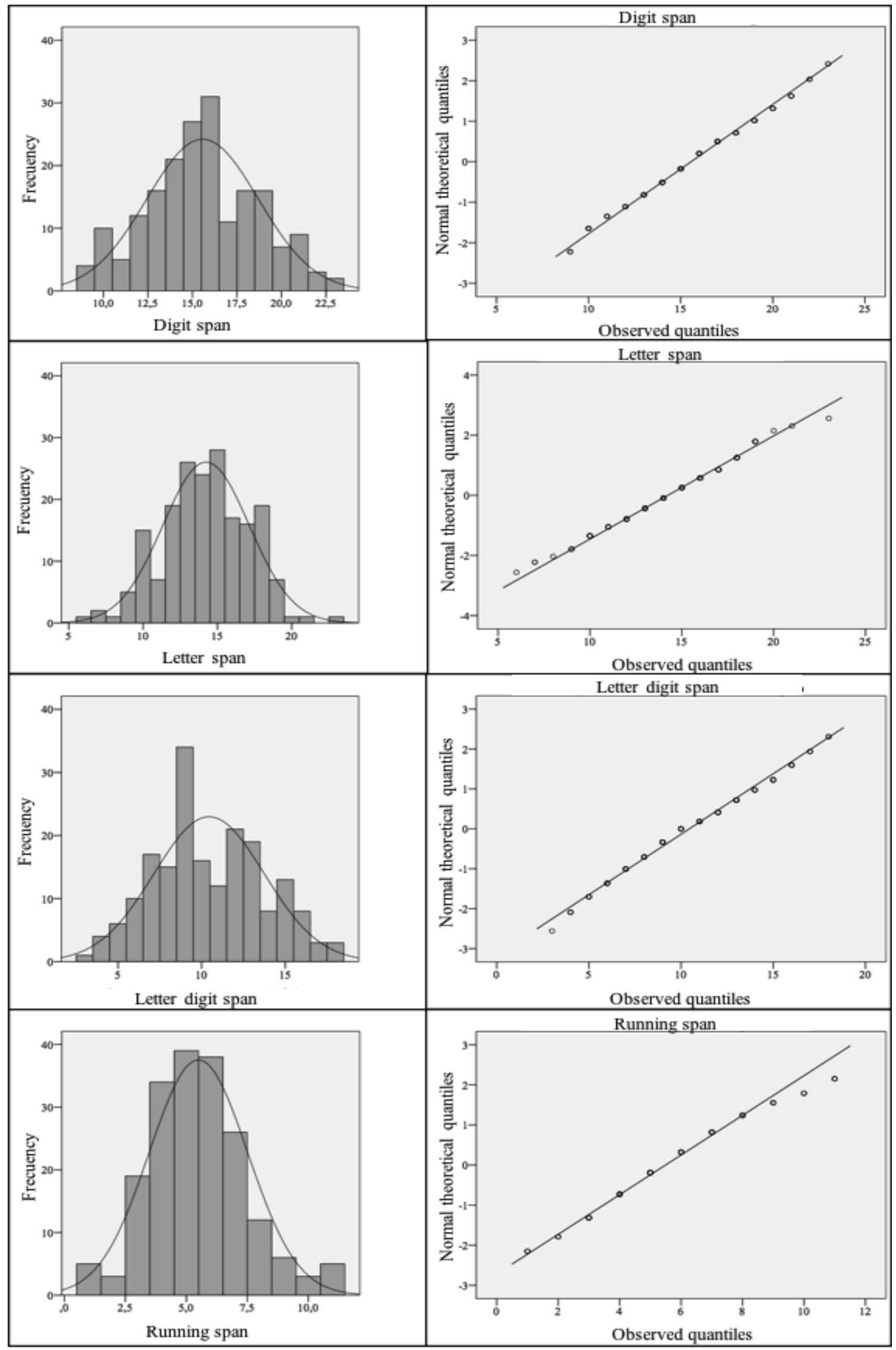

Figure 1. Working memory task scores histograms with adjustment to a normal distribution and QQ's plots. 


\section{Results}

The score of each task was the total number of items recalled correctly. The analyzes showed all distributions were symmetrical and mesocuric even though the fit test for a normal distribution of Kolmogorov-Smirnov (KS) showed that the distributions were significantly different from the percentiles of a normal theoretical distribution (see Table 1). Nevertheless, a normal fit can be inferred by observing the histograms and the Q-Q plots (see Figure 1).

The reliability determined by internal consistency analysis demonstrated that all the tests have good reliability, with indices greater than .78 (see Table 1).

Pearson's r-moment correlation showed significant associations of moderate intensity among all the verbal working memory tests (between $r=.37$ and $r=.53$; see Table 2).

Subsequently, exploratory factor analysis was performed; two latent factors emerged by employing the main component method with oblimin rotation. Firstly, as a prerequisite, it was verified that the characteristics of the intercorrelations matrix were adequate to perform this type of analysis and it was further confirmed that the matrix was not identical, $\mathrm{KMO}=.76 ; \chi^{2}$ (6) $=190.90, p<.001$. The analysis indicated that the two factors together accounted for $76.04 \%$ of the total variance of the scores. In Table 2, the correlation between the test and factor loadings above .50 are presented. In the table, a factor that saturates the scores of Letter-Digit span and Running span, and a second that saturates the scores of Digit span and Letter span is revealed.

Table 2

Correlations between Verbal Working Memory Scores and Factorial Loads

\begin{tabular}{|c|c|c|c|c|c|}
\hline & 1. & 2. & 3. & Factor 1 & Factor 2 \\
\hline 1. Digit span & 1 & & & .93 & \\
\hline 2. Letter span & $.49 * *$ & 1 & & .78 & \\
\hline 3. Letter digit span & $.47 * *$ & $.37 * *$ & 1 & & .61 \\
\hline 4. Running span & $.47 * *$ & $.43 * *$ & $.53 * *$ & & .97 \\
\hline
\end{tabular}

$* * p<.01$

In order to verify the factor structure found in the exploratory factor analysis, confirmatory factor analysis was conducted (Arbuckle, 2014). The first factor saturated the Digit span and Letter span scores, and the second factor the Letter-Digit span and Running span scores.

The resulting model showed an excellent fit to the data, with an insignificant error $\left[\chi_{(1)}^{2}\right.$ $=0.71, p=.40 ; \chi^{2} / d f=0.71 ; \mathrm{AGFI}=.99 ; \mathrm{CFI}$ $=1.00 ; \mathrm{TLI}=1.00 ; \mathrm{RMSEA}=.00]$. When analyzing the regression weights, a strong factorial load of latent factors of the memory scores with values larger than .65 and a strong correlation between the factors emerged. The regression weights of the proposed model are depicted in Figure 2.

\section{Discussion}

The aim of Study 1 was to construct and obtain indicators about the reliability and validity of a battery of verbal working memory: the BIMeT-V. Four tasks were designed: two assessed the storage and retention of verbal information, that is, short-term memory and two measured concurrent storage and processing information, that is, working memory. 


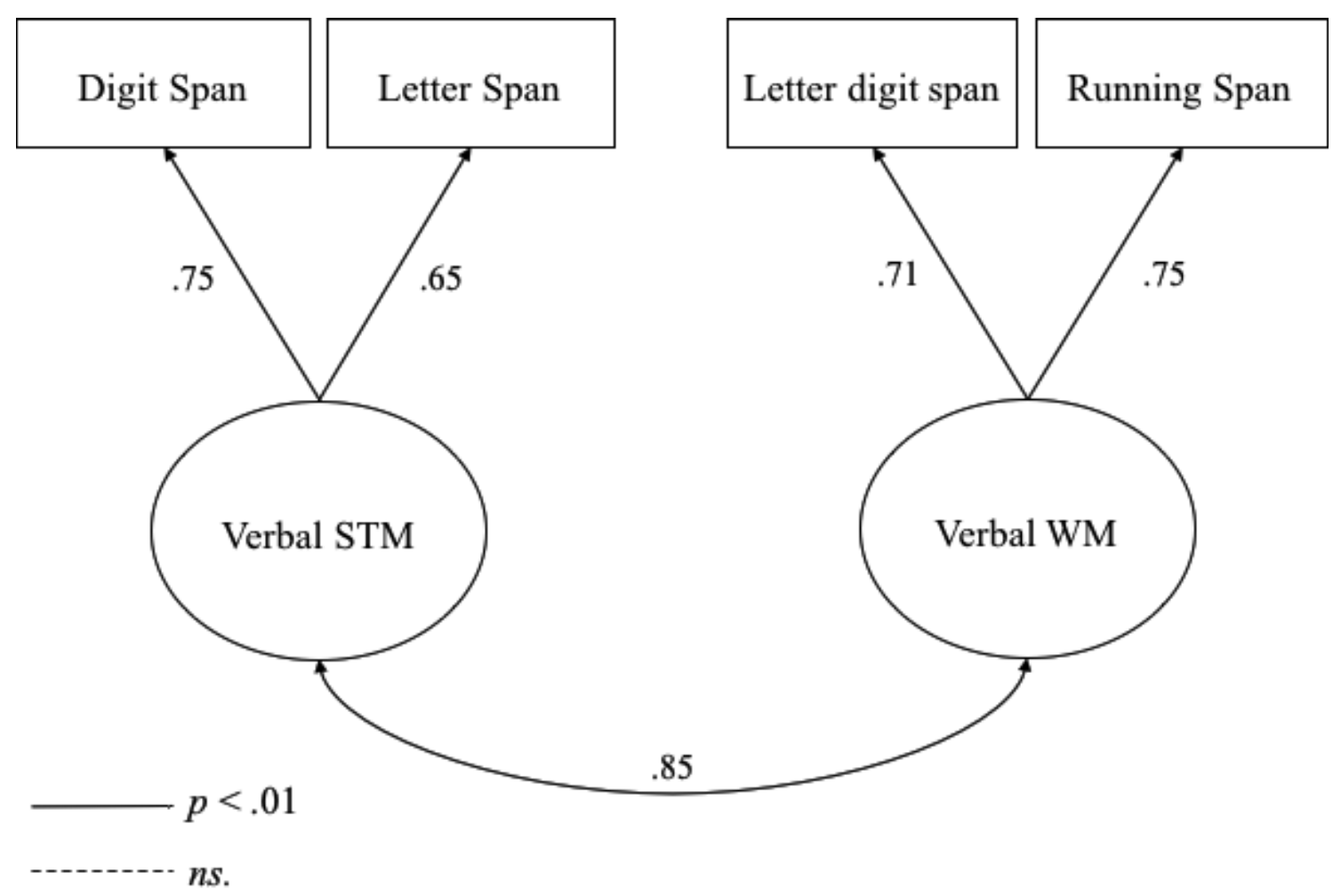

Figure 2. A model of two latent factors of verbal working memory.

The results showed that the internal consistency, as a measure of reliability, of the four verbal working memory tasks was very good. In relation to construct validity, correlation analysis showed positive and significant associations between all the task scores. The data retention tests, namely, Digit span and Letter span showed a slightly stronger association with each other in comparison to the association found between the storage and concurrent processing task scores that is, Letter-Digit span and Running span. Exploratory factor analysis showed the storage tasks were grouped in one factor, and the storage and concurrent processing tasks in another. Confirmatory factor analysis confirmed the two-factor structure of verbal working memory: storage and concurrent processes. The factor loadings demonstrated that letter span and digit span are grouped in one factor, and running span and letter-digit span are grouped in another.

In accordance with these results, it may be concluded that the BIMeT-V is a reliable and valid verbal working memory instrument; it comprises two tasks that measure verbal shortterm memory and two that assess verbal working memory. Furthermore, in conjunction with the visuospatial Computerized Working Memory Battery (Batería Informatizada de Memoria de Trabajo viso-espacial [BIMeT-VE]; Injoque-Ricle, Barreyro, Formoso, \& Burin, 2018), the BIMeT-V measures the working memory components that were proposed by Baddeley in the original working memory model comprehensively (Baddeley, 2012; Baddeley \& Hitch, 1974). As noted previously, in Argentina, no batteries, based on Baddeley's model (Baddeley, 1986, 2007, 2010), have been designed to specifically assess the components of working memory; hence, the significance of BIMeT-VE. In Argentina, in order to evaluate working memory and its components, it is common to employ working memory subtests found in intelligence scales (Kaufman \& Kaufman, 1983; Wechsler, 1998, 2003, 2012).

\section{Study 2}

The aim of the second study was to explore the relationship between the verbal information storage component of working memory, that is, 
verbal short-term memory, and the verbal storage and concurrent processing component of working memory, namely, verbal working memory with verbal reasoning and text comprehension.

\section{Method}

Participants. The sample consisted of 114 university students, of whom 85 were female (74.6\%) between the ages of 18 and 28 years $(M$ $=20.99, S D=2.40$ ). Participation was voluntary and the anonymity of all the respondents was assured.

\section{Instruments}

Verbal Reasoning by means of the Differential Aptitude Test (Bennett et al., 1992). The Differential Aptitude Test assesses one's ability to understand concepts, and generate abstractions and/or generalizations. Incomplete sentences that present analogies between two terms are presented. Participants are required to choose from five options of pairs of words in order to complete a sentence. The scoring criterion is detailed in the manual (Bennett et al., 1992).

Comprehension of Expository Texts Test. To assess text comprehension, an expository text from the area of natural sciences, namely, Mars, return to the red planet by John Updike (2009) in conjunction with a questionnaire were employed. Before the BIMeT-V was designed, the program, Expository Text Analysis Tool (Vidal-Abarca et al., 2002) was used to analyze the semantic and conceptual relations of explicit textual ideas in the text in order to identify sentences that require the reader to come up with explanations that are based on inferences of concepts. Eleven sentences that required inferences were identified. Based on these sentences, 11 inferential questions were asked after the text was read. Each question was developed to allow the participant to respond to the inference that should have been generated if he or she carefully understood the text. The scoring criteria used were as follows: 1 point was assigned for a response that contained an explicit reference to the inference and no points were awarded when the subject did not answer the question or if he or she responded incorrectly. For example, the correct answer for the question that concerned itself with the consequences the movements of Mars had for the ancients was that they saw it as violent or sinister, different from the rest of the stars.

Verbal Computerized Working Memory Battery (BIMeT-V). The BIMet-V, as described in Study 1, comprises Digit Span, Letter Span, Letter-Digit Span and Running Span.

Procedure. The participants were tested during two sessions of approximately 30 minutes each. In the first session, the BIMeT was administered; the same procedure implemented in Study 1 was followed. During the second session, the verbal reasoning and comprehension tests were administered; the presentation order was counterbalanced.

Data Analysis. Initially, correlation analyses were conducted to investigate the degree of association between the verbal reasoning scores and text comprehension scores with the verbal working memory scores. Subsequently, a full SEM analysis was carried out to explore the interplay between the variables.

\section{Results}

In Table 3, the mean values, standard deviations, minimum and maximum values, asymmetry and kurtosis of the administered tests scores are presented.

Correlation analysis was then performed by employing Pearson's $r$-moment correlation. In Table 4, the correlations between the tests of memory, reasoning and comprehension are displayed.

The results of the correlation analysis showed that the scores from the working memory tasks had significant and positive associations of moderate intensity between them (from $r=.35$ to $r=.56$ ). The verbal reasoning scores showed low intensity correlations with the text comprehension scores $(r=.28)$. The analysis also detected positive and significant 
Table 3

Descriptive Statistics of Task Scores

\begin{tabular}{lcccccc}
\hline & $M$ & $S D$ & Min. & Max. & Skewness & Kurtosis \\
\hline Digit span & 15.23 & 3.24 & 9 & 21 & -0.11 & -0.81 \\
Letter span & 14.00 & 2.90 & 6 & 19 & -0.41 & -0.46 \\
Letter digit span & 10.65 & 3.20 & 4 & 18 & 0.13 & -0.62 \\
Running span & 5.82 & 2.14 & 1 & 11 & 0.38 & -0.09 \\
Verbal reasoning & 12.25 & 2.78 & 2 & 17 & -0.95 & 1.10 \\
Text comprehension & 3.17 & 1.83 & 0 & 9 & 0.73 & 0.64 \\
\hline
\end{tabular}

Table 4

Correlations between Tasks Scores

\begin{tabular}{lccccc}
\hline & 1. & 2. & 3. & 4. & 5. \\
\hline 1. Digit span & 1 & & & & \\
2. Letter span & $.56^{* *}$ & 1 & & & \\
3. Letter digit span & $.48^{* *}$ & $.35^{* *}$ & 1 & & \\
4. Running span & $.54^{* *}$ & $.47^{* *}$ & $.57^{* *}$ & 1 & 1 \\
5. Verbal reasoning & $.20^{*}$ & $.20^{*}$ & $.36^{* *}$ & $.33^{* *}$ & $.28^{* *}$ \\
6. Text comprehension & $.24^{* *}$ & .14 & $.34^{* *}$ & $.43^{* *}$ & \\
\hline
\end{tabular}

${ }^{* *} p<.01, * p<.05$.

low intensity correlations (between $r=.20$ and $r=.24$ ) between the short-term memory tasks scores (Digit span and Letter span) and the verbal reasoning and text comprehension scores; the Letter span scores were the exception in that they did not show a significant correlation with the text comprehension scores. Furthermore, moderate intensity associations (between $r=.33$ and $r=.43$ ) were found between the working memory tasks scores and the verbal reasoning and text comprehension scores. These results are presented in Table 4.

Finally, a full SEM analysis was conducted. Accordingly, a model of relationship between the components of working memory, verbal reasoning and text comprehension tests was proposed. The model included two latent factors: one that saturated short-term memory tasks scores and a second one that saturated working memory tasks scores with both factors that had a direct effect on the verbal reasoning and text comprehension tests scores; this is depicted in Figure 3.

The results of the full SEM analysis showed that the proposed model had a very good adjustment to the empirical data obtained from the variances and covariances $\left[\chi^{2}(5)=3.75\right.$, $p=.59, \chi^{2} / g l=0.75$, AGFI $=.96$, CFI $=1.00$, TLI $=1.00$, RMSEA $=.00]$. When observing the regression weights of the model, which is depicted in Figure 3, it was found that memory factors significantly saturated memory tasks scores with values between .69 and .82 . The memory factors were strongly correlated with each other. With reference to the incidence of memory factors related to verbal reasoning and text comprehension tests scores, it was found that the factor that saturated the short-term memory 
tasks scores did not have a significant load on either, but the factor that saturated working memory tasks scores had a significant moderatehigh and high intensity load on both the verbal reasoning and text comprehension tests scores. On the contrary, the verbal reasoning and text comprehension tests scores did not demonstrate any significant associations between each other.

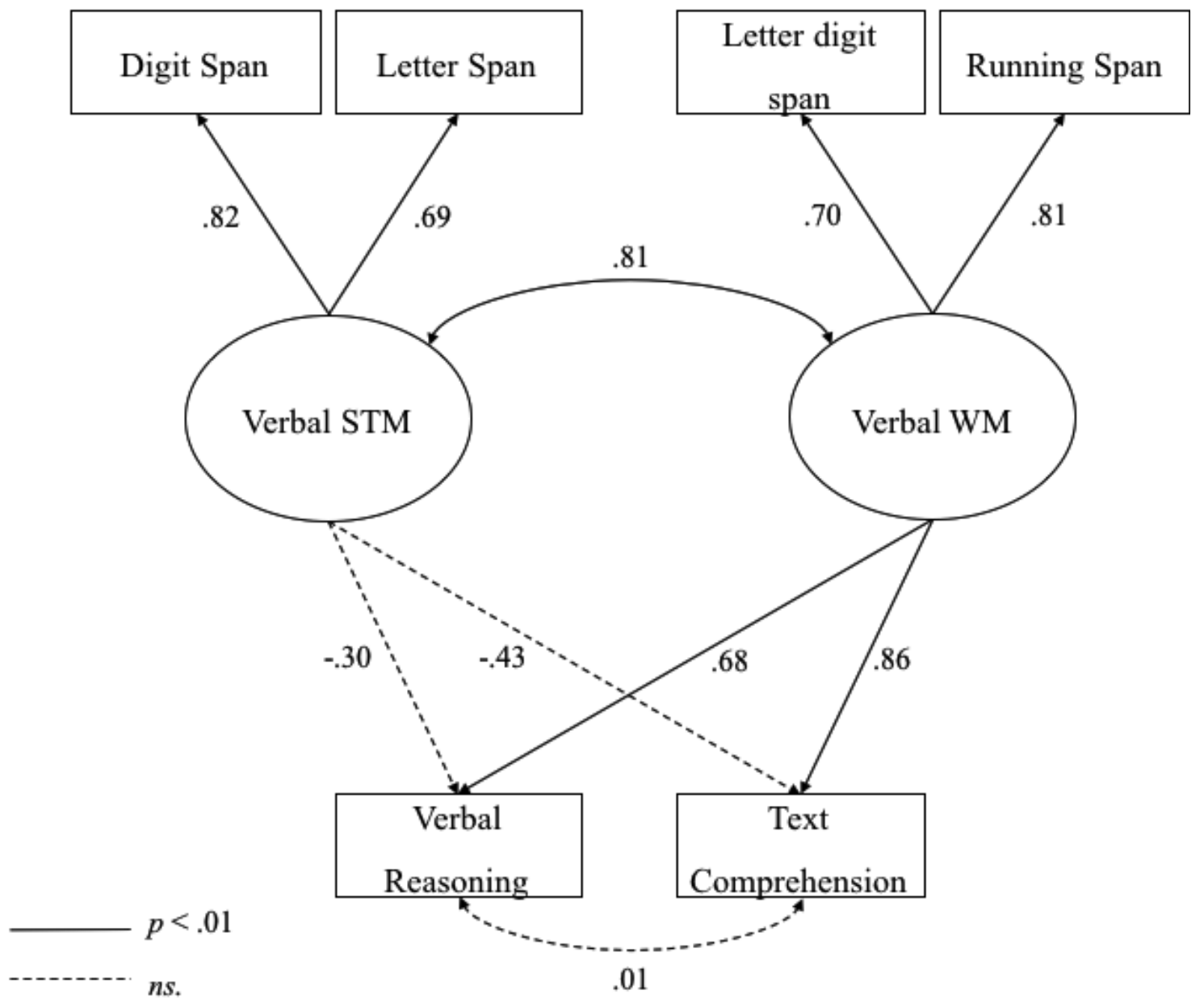

Figure 3. Model of two latent factors of verbal working memory and their relation with verbal reasoning and text comprehension.

\section{Discussion}

The purpose of Study 2 was to analyze the role of the storage and storage-processing components of working memory on verbal reasoning and text comprehension.

The results showed that the participants' performance in the verbal reasoning test and in expository text comprehension were associated with all working memory tasks.

On the contrary, the complete SEM analysis demonstrated that only the verbal storage and concurrent processing component of working memory had a significant effect on the performances of the participants in the verbal reasoning and expository text comprehension tasks, while the exclusive verbal storage component of working memory did not demonstrate a significant effect on verbal reasoning and text comprehension.

These results concur with those found in a wide range of studies (Barreyro et al., 2012; Broadway \& Engle, 2010; Carretti et al., 2009; Colom et al., 2008; Colom et al., 2007; Hannon, 2012; Oberauer et al., 2008; Prat et al., 2016) that found that verbal reasoning skills, defined as the ability to abstract, generalize and establish relationships between concepts or 
ideas present in a problem as well as the ability to comprehend an expository text, that is, to construct a coherent mental representation in memory, are cognitive abilities supported by the capacity to store and process verbal information concurrently in working memory, and to a lesser extent, the verbal information storage capacity of working memory. From a theoretical point of view, working memory is associated with text comprehension and verbal reasoning; the results of the present study, by employing a novel battery to assess verbal working memory, are in accordance with this perspective.

\section{General Discussion}

This project comprised two objectives. The first one aimed to construct a verbal working memory battery (BIMeT-V) in order to allow the researchers to assess the component in charge of temporary retention of information as well as the component responsible for the storage and concurrent processing of information. The second objective was to examine the relationship between the verbal components of working memory, verbal reasoning, and text comprehension.

In Study 1, a sample of 190 college students completed four verbal working memory tasks that were designed to be included in the battery: Digit Span, Letter Span, Letter-Digit Span, and Running Span. The analysis showed that all the tests presented very good reliability indexes and further demonstrated evidence of construct validity because the verbal storage tests, namely, Digit span and Letter span, were grouped together. The verbal storage and processing tests, that is, Letter-Digit Span and Running Span, were also grouped together. In accordance with the model proposed by Baddeley $(2010,2012)$, the first two tasks were concluded to be measures of the phonological loop, and the second group an assessment of the central executive; specifically, the resources linked to the maintenance and processing of verbal information.

In Study 2, a sample of 114 college students completed the BIMeT-V in conjunction with a verbal reasoning test and an expository text comprehension test. The results obtained from the correlation analysis showed that the memory tasks were positively and significantly associated with the results of the comprehension and reasoning tests; there were higher association rates between the concurrent processing and storage tests, and the measures of reasoning and text comprehension. The full SEM analysis showed that the verbal short-term memory factor, which is linked to the phonological loop of Baddeley's model, did not significantly affect performance in verbal reasoning and text comprehension. Consequently, the pure retention amplitude of verbal information would not have played an important role in the performance of tasks of a high hierarchical level such as reasoning and comprehension. On the other hand, the verbal working memory factor, which is linked to the central executive of the Baddeley model, showed a direct and significant effect on the tasks of reasoning and comprehension. This allowed the researchers to affirm that the ability to abstract, generalize and establish relationships between concepts or ideas that are present in a problem, premise or sentences, linked to verbal reasoning, and the ability to construct a coherent mental representation of the meaning of the text in memory, thus, integrating and inferring information necessary for comprehension, require verbal working memory resources that are involved in the storage and concurrent processing of verbal information.

Since the 1990s (Kyllonen \& Christal, 1990), the concept of working memory has emerged as one of the cognitive processes that has a strong impact on high level skills such as reasoning and comprehension. It is important to understand which of the working memory components affect the different aspects and processes of those cognitive abilities. Since reasoning involves multiple skills such as verbal, abstract and mechanical, and/or aptitudes (Bennett et al., 1992) and comprehension includes different interrelated components for example, the construction of a macrostructure, information integration, inferences and monitoring, and these 
vary according to the type of text and the purpose of the reader (Cain \& Oakhill., 2014; Cornoldi \& Oakhill, 2013; Oakhill, Hartt, \& Samols, 2005), future research should further investigate the relationship between the components of working memory and the different aspects of reasoning as well as the different components of comprehension.

\section{Authors' Contributions}

Substantial contribution in the concept and design of the study: Juan Pablo Barreyro, Irene Injoque Ricle, Jesica Formoso, Debora Inés Burin.

Contribution to data collection: Juan Pablo Barreyro, Irene Injoque Ricle.

Contribution to data analysis and interpretation: Juan Pablo Barreyro, Irene Injoque Ricle.

Contribution to manuscript preparation: (Juan Pablo Barreyro, Irene Injoque Ricle, Jesica Formoso.

Contribution to critical revision, adding intelectual content: Juan Pablo Barreyro, Irene Injoque Ricle, Jesica Formoso, Debora Inés Burin.

\section{Conflicts of interest}

The authors declare that they have no conflict of interest related to the publication of this manuscript.

\section{References}

American Educational Research Association, American Psychological Association, \& National Council on Measurement in Education. (2000). Standards for Educational and Psychological Testing. Washington, DC: American Educational Research Association.

Arbuckle, J. L. (2014). IBM SPSS AMOS 22 User's Guide. Mount Pleasant, SC: Amos Development Corporation.

Baddeley, A. D. (1986). Working memory. Oxford, UK: Clarendon Press.

Baddeley, A. D. (2007). Working memory, thought, and action. Oxford, UK: Oxford University Press.
Baddeley, A. D. (2010). Working memory. Current Biology, 20(4), 136-140. doi: 10.1016/j. cub.2009.12.014

Baddeley, A. D. (2012). Working Memory: Theories, models, and controversies. Annual Review of Psychology, 63, 1-29. doi: 10.1146/annurevpsych-120710-100422

Baddeley, A. D., \& Hitch, G. J. (1974). Working memory. In G. H. Bower (Ed.), The Psychology of Learning and Motivation: Advances in Research and Theory (Vol. 8, pp. 47-90). New York: Academic Press.

Barreyro, J. P., Cevasco, J., Burin, D. I., \& Molinari, C. (2012). Working memory capacity and individual differences in the making of reinstatement and elaborative inferences. Spanish Journal of Psychology, 15(2), 471-479. doi: 10.5209/rev SJOP.2012.v15.n2.38857

Bennett, G. K., Seashore, H. G., \& Wesman, A. G. (1992). Tests de Aptitudes Diferenciales, DAT. Manual forma T. Buenos Aires: Paidós.

Bilker, W. B., Wierzbicki, M. R., Brensinger, C. M., Gur, R. E., \& Gur, R. C. (2014). Development of Abbreviated Eight-Item Form of the Penn Verbal Reasoning Test. Assessment, 21(6), 669678. doi: $10.1177 / 1073191114524270$

Bohn-Gettler, C. M., \& Kendeou, P. (2014). The interplay of reader goals, working memory, and text structure during reading. Contemporary Educational Psychology, 39(3), 206-219. doi: 10.1016/j.cedpsych.2014.05.003

Broadway, J. M., \& Engle, R. W. (2010). Validating running memory span: Measurement of working memory capacity and links with fluid intelligence. Behavior Research Methods, 42(2), 563-570. doi: 10.3758/BRM.42.2.563

Cain, K., \& Oakhill, J. (2014). Reading comprehension and vocabulary: Is vocabulary more important for some aspects of comprehension?. L'Année Psychologique, 114(4), 647-662. doi: 10.4074/ S0003503314004035

Calvo, M. G. (2004). Relative contribution of vocabulary knowledge and working memory span to elaborative inferences in reading. Learning and Individual Differences, 15, 53-65.

Carretti, B., Borella, E., Cornoldi, C., \& De Beni, R. (2009). Role of working memory in explaining the performance of individuals with specific reading comprehension difficulties: A meta-anal- 
ysis. Learning and Individual Differences, 19, 246-251. doi: 10.1016/j.lindif.200810.002

Colom, R., Abad, F. J., Quiroga, M. A., Shih, P. C., \& Flores-Mendoza, C. (2008). Working memory and intelligence are highly related constructs, but why? Intelligence, 36, 584-606. doi: 10.1016/j. intell.2008.01.002

Colom, R., Escorial, S., Shih, P. C., \& Privado, J. (2007). Fluid intelligence, memory span, and temperament difficulties predict academic performance of young adolescents. Personality and Individual Differences, 42(8), 1503-1514. doi: 10.1016/j.paid.2006.10.023

Cornoldi, C., \& Oakhill, J. V. (2013). Reading comprehension difficulties: Processes and intervention. Oxford, UK: Routledge.

Cowan, N. (2012). Working memory capacity. New York: Psychology press.

Currie, N. K., \& Cain, K. (2015). Children's inference generation: The role of vocabulary and working memory. Journal of Experimental Child Psychology, 137, 57-75. doi: 10.1016/j. jecp.2015.03.005

Daneman, M., \& Carpenter, P. A. (1980). Individual differences in working memory and reading. Journal of Verbal Learning and Verbal Behavior, 19, 450-466. doi: 10.1016/S00225371(80)90312-6

Daneman, M., \& Merikle, P. M. (1996). Working memory and language comprehension: A metaanalysis. Psychonomic Bulletin \& Review, 3, 422-433. doi: 10.3758/BF03214546

Daneman, M., \& Tardif, T. (1987). Working memory and reading skill reexamined. In M. Coltheart (Ed.), Attention and performance XII: The psychology of reading. Hillsdale, NJ: Erlbaum.

Engle, R. W., Tuholski, S. W., Laughlin, J. E., \& Conway, A. R. A. (1999). Working memory, short-term memory and general fluid intelligence: A latent variable approach. Journal of Experimental Psychology: General, 128, 309331. doi: 10.1037/0096-3445.128.3.309

Gernsbacher, M. A., \& Kaschak, M. P. (2013). Text Comprehension. In D. Reisberg (Ed.), The Oxford Handbook of Cognitive Psychology (pp. 462-474). Oxford, UK: Oxford University Press.

Hannon, B. (2012). Understanding the relative contributions of lower level word processes, higher level processes, and working memory to reading comprehension performance in proficient adult readers. Reading Research Quarterly, 47(2), 125-152. doi: 10.1598/0710.33

Hannon, B., \& Daneman, M. (2001). A new tool for measuring and understanding individual differences in the component processes of reading comprehension. Journal of Educational Psychology, 93, 103-128. doi: 10.1037/00220663.93.1.103

Injoque-Ricle, I., Barreyro, J. P., Formoso, J., \& Burin, D. (2018). Working memory, processing speed and general intelligence: Possible models of relations with visuospatial working memory using the visuospatial Computerized Working Memory Battery (BIMeT-VE). Trends in Psychology, 26(1), 413-427. http://dx.doi. org/10.9788/tp2018.1-16

Just, M. A., \& Carpenter, P. A. (1992). A capacity theory of comprehension: Individual differences in working memory. Psychological Review, 99(1), 122-149.

Kane, M. J., Hambrick, D. Z., Tuholski, S. W., Wilhelm, O., Payne, T. W., \& Engle, R. W. (2004). The generality of working memory capacity: A latent-variable approach to verbal and visuo-spatial memory span and reasoning. Journal of Experimental Psychology: General, 133, 189-217.

Kaufman, A. S., \& Kaufman, N. L. (1983). Batería de evaluación de Kaufmann para niños. Madrid: TEA Ediciones.

Kendeou, P., van den Broek, P., Helder, A., \& Karlsson, J. (2014). A cognitive view of reading comprehension: Implications for reading. Learning Disabilities Research \& Practice, 29(1), 10-16. doi: 10.1111/ldrp.12025

Kintsch, W. (1998). Comprehension. A paradigm for cognition. Cambridge, MA: Cambridge University Press.

Kyllonen, P. C., \& Christal, R. E. (1990). Reasoning ability is (little more than) working memory capacity?!. Intelligence, 14, 389-433. doi: 10.1016/S0160-2896(05)80012-1

Mason, R. A., \& Just, M. A. (2007). Lexical ambiguity in sentence comprehension. Brain Research, 1146, 115-127. doi: 10.1016/j. brainres.2007.02.076

Oakhill, J. V., Hartt, J., \& Samols, D. (2005). Comprehension monitoring and working 
memory in good and poor comprehenders. Reading and Writing, 18, 657-686. doi: 10.1007/ s11145-005-3355-z

Oberauer, K., Süb, H. M., Wilhelm, O., \& Wittmann, W. W. (2008). Which working memory functions predict intelligence? Intelligence, 36 , 641-652. doi: 10.1016/j.intell.2008.01.007

Prat, C. S., Seo, R., \& Yamasaki, B. L. (2016). The Role of Individual Differences in Working Memory Capacity on Reading Comprehension Ability. In P. Afflerbach (Ed.), Handbook of Individual Differences in Reading: Reader, Text, and Context (pp. 331-347). New York: Routledge.

Sanchez, C. A., \& Wiley, J. (2006). An examination of the seductive details effect in terms of working memory capacity. Memory \& Cognition, 34, 344-355. doi: 10.3758/BF03193412

Shah, P., \& Miyake, A. (1996). The separability of working memory resources of spatial thinking and language processing: An individual differences approach. Journal of Experimental Psychology: General, 125, 4-27. doi: 10.1037/0096-3445.125.1.4

Stevenson, C. E., Heiser, W. J., \& Resing, W. C. (2013). Working memory as a moderator of training and transfer of analogical reasoning in children. Contemporary Educational Psychology, 38(3), 159-169. doi: 10.1016/j. cedpsych.2013.02.001

Süb, H. M., Oberauer, K., Wittmann, W. W., Wilhelm, O., \& Schulze, R. (2002). Workingmemory capacity explains reasoning ability and a little bit more. Intelligence, 30, 261-288.
Updike, J. (2009). Marte, regreso al planeta rojo. National Geographic España, 24(1), 2-19.

Vidal-Abarca, E., Reyes, H., Gilabert, R., Calpe, J., Soria, E., \& Graesser, A. C. (2002). ETAT: Expository Text Analysis Tool. Behavior Research Methods, Instruments, \& Computers, 34, 93-107. doi: 10.3758/BF03195428

Waters, G. S., \& Caplan, D. (2004). Verbal working memory and on-line syntactic processing: Evidence from self-paced listening. The Quarterly Journal of Experimental Psychology Section A, 57(1), 129-163. doi: 10.1080/02724980343000170

Wechsler, D. (1998). Test de inteligencia para preescolares (WPPSI). Buenos Aires: Paidós.

Wechsler, D. (2003). WAIS III: Test de Inteligencia para Adultos. Buenos Aires: Paidós.

Wechsler, D. (2012). Test de inteligencia para niños (WISC-IV) (4th ed.). Buenos Aires: Paidós.

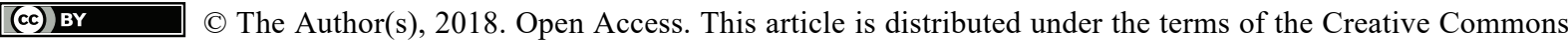
Attribution 4.0 International License (http://creativecommons.org/licenses/by/4.0/), which permits unrestricted use, distribution, and reproduction in any medium, provided you give appropriate credit to the original author(s) and the source, provide a link to the Creative Commons license, and indicate if changes were made. 